\title{
Synthesis of the Enantiomers of Thioridazine
}

\author{
Simen Antonsen*a (i) \\ Erling B. Monsen ${ }^{\mathrm{a}}$ \\ Kirill Ovchinnikov ${ }^{\mathrm{a}}$ \\ Jens M. J. Nolsøe ${ }^{a}$ \\ Dag Ekeberg ${ }^{a}$ \\ Jette E. Kristiansen ${ }^{\mathrm{b}}$ \\ Dzung B. Diep ${ }^{a}$ \\ Yngve Stenstrøma
}

a Department of Chemistry, Norwegian University of

Life Sciences, PO box 5003, 1432 Ås, Norway

Simen.antonsen@nmbu.no

${ }^{b}$ Center for Biomembrane Physics, University of Southern

Denmark, 5230, Odense, Denmark

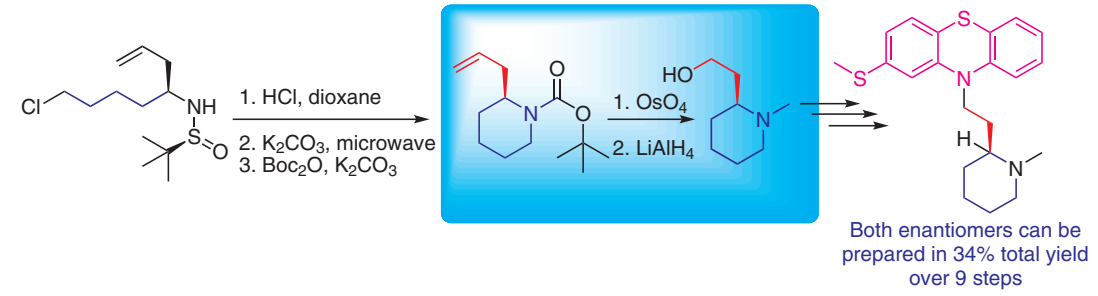

over 9 steps
Received: 22.01.2020

Accepted after revision: 03.02.2020

Published online: 17.02 .2020

DOI: 10.1055/s-0039-1690834; Art ID: so-2020-d0003-I

License terms: (C)

(c) 2020. The Author(s). This is an open access article published by Thieme under the terms of the Creative Commons Attribution License, permitting unrestricted use, distribution and reproduction, so long as the original work is properly cited.

(https://creativecommons.org/licenses/by/4.0/)

Abstract Thioridazine, a well-known antipsychotic drug, has shown promising effects on several bacterial strains (including Mycobacterium tuberculosis and methicillin-resistant Staphylococcus aureus). Suppressive effects towards selected cancer cell-lines have also been reported. However, due to adverse effects, the compound is no longer in use for the primary indication. More recent research has demonstrated that these side effects are limited to one of the two enantiomers, (+)-thioridazine. The question arises to whether the beneficial effects of thioridazine are limited to one enantiomer, or if (-)-thioridazine can prove itself to be useful in its pure enantiomeric state. The published procedures on the synthesis of the optically pure enantiomers of thioridazine were found to be unsatisfactory, either due to low optical purity, high cost, or problems scaling up. Herein, we have used an auxiliarybased strategy for the total synthesis of both enantiomers in high optical purity and good overall yield. The strategy can easily be scaled up. Both enantiomers were tested against several bacteria. Comparison of the racemic mixture, (-)-thioridazine and its (+)-antipode revealed that they have the same antimicrobial effects. Thus, the non-toxic enantiomer, (-)-thioridazine, can prove useful in this role and should be investigated further.

Key words thioridazine, antibacterial, enantiomers, total synthesis, sulfinyl aldimines

Phenothiazine drugs are well-known antipsychotic drugs. Members of this drug class include thioridazine (1), fluphenazine (2) and chlorpromazine (3), the first antipsychotic drug on the market, and methylene blue (4) (Figure 1). Thioridazine (1) was introduced as a treatment for schizophrenia and psychosis, and soon became widely used. ${ }^{1}$ Compared to chlorpromazine, thioridazine results in less pronounced extrapyramidal side effects., ${ }^{2,3}$
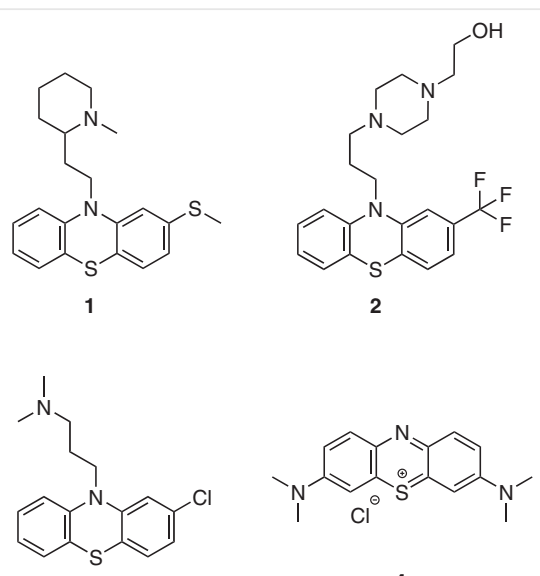

Figure 1 Structures of four well-known phenothiazines

A common side effect of antipsychotic drugs is a prolonged QT interval, i.e., the time from when the cardiac ventricles start to contract until they are finished relaxing, and this was soon reported to be the case for thioridazine. ${ }^{4}$ Therapeutic doses can cause cardiac repolarization abnormalities and prolongation of QT in a dose-dependent manner. ${ }^{5,6}$ Cases of the potentially fatal ventricular arrhythmia, Torsades de Pointes, have been reported. To date, 41 sudden deaths in patients have been associated with treatment with thioridazine..$^{5-12}$ Around the turn of the millennium, the risks for these severe side effects were found to be higher than for other antipsychotic drugs. ${ }^{13}$ Accordingly, branded versions of thioridazine were withdrawn in 2005. ${ }^{14}$

In addition to antipsychotic properties, several members of the phenothiazine class have significant antimicrobial activity against a wide range of bacteria. ${ }^{14}$ However, thioridazine has not been used clinically as an antibacterial agent. Nevertheless, thioridazine has attracted renewed 
interest in recent years due to its activity against multidrug-resistant and extensively drug-resistant tuberculosis. ${ }^{15}$ Particularly interesting are reports of increased sensitivity of drug-resistant Mycobacterium tuberculosis and methicillin-resistant Staphylococcus aureus (MRSA) to thioridazine. ${ }^{7,15,16}$ The suggested mechanism of action is inhibition of bacterial efflux pumps. ${ }^{17}$

Moreover, it has been demonstrated that thioridazine is concentrated in macrophages. Infections in macrophagerich tissue (e.g., lung, kidney, spleen and liver) include tuberculosis. Consequently, lower doses are expected to be needed for the treatment of such infections, compared to treatment of psychosis. ${ }^{18-21}$

Furthermore, thioridazine has the ability to suppress the growth of several types of cancer cells. ${ }^{22}$ Recently, studies revealed thioridazine to target cancer stem cells selectively. ${ }^{23-25}$ It has also been demonstrated that thioridazine makes multidrug-resistant cancer cells vulnerable to cytotoxic agents to which they were originally resistant. ${ }^{26}$

The majority of the reports on thioridazine are concerned with the biology of the commercially available thioridazine, which is the hydrochloride of the racemate. During the last 30 years, several groups have investigated the properties of the separate enantiomers, rather than the racemate. Experiments in rat brains revealed that the (+)enantiomer has approximately 2.7 times greater affinity than the (-)-enantiomer for the $D_{2}$ dopamine receptor, the inhibition of which results in the antipsychotic effect of thioridazine. The (+)-enantiomer also has 4.5 times higher affinity for the norepinephrine $\alpha 1$ receptor. In contrast, (-)thioridazine has 10 times higher affinity for the $D_{1}$ dopamine receptor. ${ }^{27,28}$

The (-)-enantiomer causes significantly less ventricular action potential prolongation of the rabbit papillary muscle compared to (+)-thioridazine. ${ }^{29}$ With its reduced antipsychotic effects and reduced prolongation of APD, (-)-thioridazine warrants further biological investigation.

There are only a couple of published procedures for the preparation of enantiomers of thioridazine. ${ }^{30-32}$ Bourquin et al. reported the first synthesis of $\mathbf{1}$, starting from racemic piperidine alcohol 5 (Scheme 1). Enantiomers of 1 were separated via chiral resolution employing di-p-tolyl-L-tartaric acid as a chiral derivatizing agent, making this a rather inefficient synthesis of the desired enantiomer. ${ }^{30}$

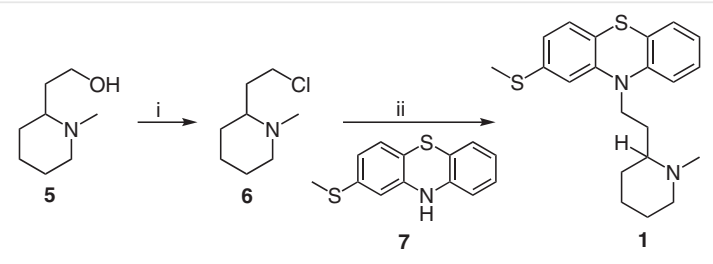

Scheme 1 Synthesis by Bourquin et al. ${ }^{30}$ Reagents and conditions: (i) thionyl chloride, $\mathrm{CHCl}_{3}, 70{ }^{\circ} \mathrm{C}, 90 \%$ yield; (ii) $\mathrm{NaNH}_{2}$, phenothiazine 7 , $\mathrm{PhCH}_{3}$, xylene, $180^{\circ} \mathrm{C}, 60 \%$ yield.
An alternative to this approach starts with optically pure piperidine-2-carboxylic acid; ${ }^{33}$ the synthesis is shown in Scheme 2. Piperidine-2-carboxylic acid is treated under Eschweiler-Clarke conditions followed by esterification. The ester is reduced using $\mathrm{LiAlH}_{4}$ and transformed into the corresponding nitrile. The nitrile is hydrolyzed with hydrochloric acid in methanol and the resulting methyl ester is reduced to the alcohol and treated with thionyl chloride. The specific rotation of the resulting chloride (-)-6 was compared with the patent literature in order to define the absolute stereochemistry of (+)-1 and (-)-1 as $R$ and $S$, respectively..$^{33}$ It should also be noted that (-)-5 can be made through chiral resolution, but with tedious and low-yielding nine recrystallizations to obtain sufficient optical purity. Most of the eight steps are high yielding, but the overall yield is $8 \%$ and the starting material, piperidine-2-carboxylic acid, is quite expensive and constitutes a limitation for scale up.

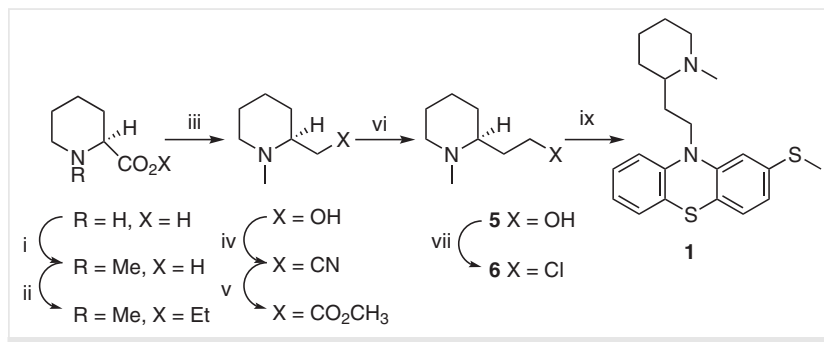

Scheme 2 Synthesis of the thioridazine developed by Patrick and Singletary. ${ }^{33}$ Reagents and conditions: (i) $\mathrm{HCO}_{2} \mathrm{H}, \mathrm{CH}_{2} \mathrm{O}, 16 \mathrm{~h}$, reflux, 76\%; (ii) $\mathrm{AcCl}, 3 \mathrm{M} \mathrm{HCl}$, EtOH, 18 h, reflux, 89\%; (iii) $\mathrm{LiAlH}_{4}$, Et $2 \mathrm{O}$, reflux, 6 h, $81 \%$; (iv) $\mathrm{KCN}, 18$-crown-6-ether, $\mathrm{MeCN}_{3} \mathrm{Bu}_{3} \mathrm{P}, 36 \mathrm{~h}$, reflux, $80 \%$; (v) $\mathrm{HCl}$ in $\mathrm{MeOH}, 2^{\circ} \mathrm{C}, 67 \%$; (vi) $\mathrm{LiAlH}_{4}, \mathrm{Et}_{2} \mathrm{O}$, reflux, $6 \mathrm{~h}, 90 \%$; (vii) $\mathrm{CHCl}_{3}$, $\mathrm{HCl}$ (gas), $\mathrm{Cl}_{2} \mathrm{SO}, 5 \mathrm{~h}, 0{ }^{\circ} \mathrm{C}, 51 \%$; (viii) $\mathrm{NaOH}, 7, \mathrm{PhCH}_{3}$, reflux, $3 \mathrm{~h}, 60 \%$ (for final reaction refer to Bourquin et al. ${ }^{30}$ ).

Another alternative is the procedure reported by Choi et al., in which the menthyl carbamate of $\mathbf{1}$ is prepared and the diastereomers are separated by flash chromatography. However, the carbamate is easily hydrolyzed, which makes the separation step hard to scale up. $\mathrm{LiAlH}_{4}$ reduction of these carbamates gives the enantiomers of $\mathbf{1} .^{31}$ This procedure gives good enantiomeric excess, but the overall yield is poor. In addition, the production of larger quantities is laborious, due to the bottleneck of the diastereomer separation step.

Mohammad et al. reported the total syntheses of racemic thioridazine and isotope-labeled analogues. ${ }^{34,35}$ The strategy is elegant, but not suited for asymmetric synthesis. Accordingly, we decided to develop our own total synthesis that can be scaled up to produce larger volumes of both enantiomers.

Our key step involves the preparation of enantiopure alcohol 5. The retrosynthesis is depicted in Scheme 3. The piperidine-2-carboxylic acid approach is opportune, as the stereogenic center is present in the starting material. 
However, previously we have observed the lability towards racemization of $\alpha$-amino acids during elongation. ${ }^{36}$ The allyl moiety is easy to handle, and can be oxidized to an aldehyde in a straightforward manner. For asymmetric synthesis of amines, chiral auxiliaries, for example, the use of chiral sulfonamides, are excellent choices. It is also known that sulfonamides can be selectively alkylated in an aqueous environment. ${ }^{37}$ After hydrolysis, the sulfonamides can be recovered and reused. ${ }^{38}$

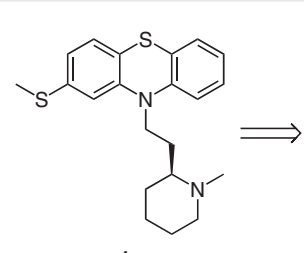

1

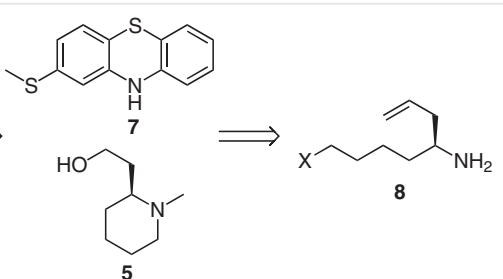

Scheme 3 Retrosynthesis

First, we aimed for the $S$-enantiomer of $\mathbf{1}$. Condensation of 5-chloropentanal 9 with (S)-tert-butanesulfinamide, gave the corresponding $\mathrm{N}$-tert-butanesulfinyl aldimine $\mathbf{1 0}$ (Scheme 4). Indium-mediated allylation of $(R)-\mathbf{1 0}$ in aqueous media, gave $(R, S)$-11 and $(R, R)$-11 in close to 10:1 diastereomeric ratio and quantitative yield. The two diastereomers were separated by flash chromatography to give single diastereomers, and the major product, $(R, S)-\mathbf{1 1}$, was used in the next reaction. ${ }^{39}$

Acid-mediated hydrolysis of the tert-butanesulfonamide, with a subsequent intramolecular alkylation, best achieved using microwave heating, yielded the piperidine motif. Next, the amine was protected as the tert-butylcarbamate $(S)-12$, to avoid possible formation of the $N$-oxide, during the Lemieux-Johnson oxidation. The oxidation worked well, yielding aldehyde $(S)$-13. Focusing on the active nitrogen in the phenothiazine ring, reductive amination was envisaged as an alternative. However, this approach proved unsuccessful as we only recovered starting material.

The carbamate functionality was hydrolyzed, and the resulting piperidine was methylated under EschweilerClarke conditions. Focusing on the active nitrogen in the phenothiazine ring, reductive amination was considered as an alternative. However, this also proved unsuccessful.

Finally, $\mathrm{LiAlH}_{4}$ reduction of the carbamate (S)-13 gave amino alcohol $(S)-\mathbf{5}$. All data are in accordance with published data. Amino alcohol (S)-5 was transformed into the corresponding chloride $(S)-\mathbf{6}$ and coupled with phenothiazine $\mathbf{7}$, to give the $(S)$-enantiomer of thioridazine. ${ }^{30}$

Corresponding reactions starting from $(R)$-tert-butanesulfinamide gave the $(R)$-enantiomer of thioridazine.
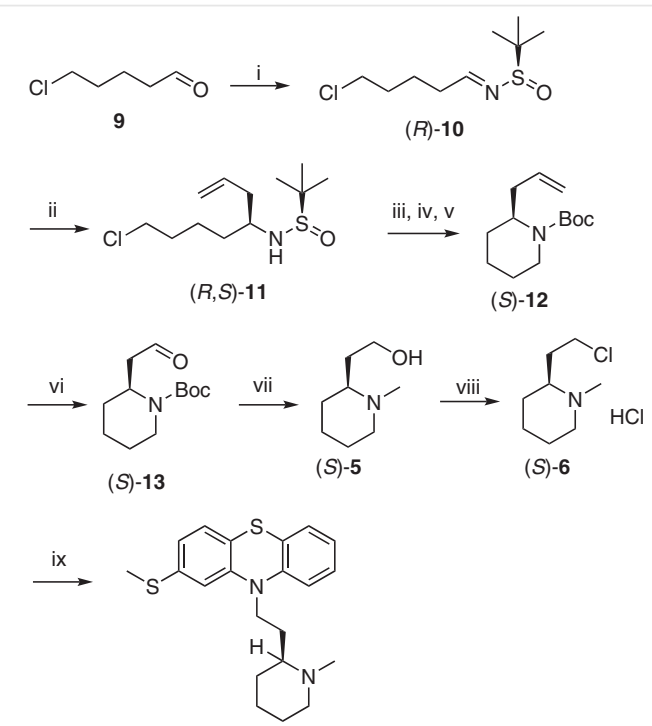

(S)-1

Scheme 4 Synthesis of the S-enantiomer of thioridazine. Reagents and conditions: (i) (S)-tert-butanesulfinamide, $\mathrm{CuSO}_{4}, \mathrm{CH}_{2} \mathrm{Cl}_{2}$, r.t., overnight, 91\%; (ii) allyl bromide, $\mathrm{NaBr}, \mathrm{In}, \mathrm{H}_{2} \mathrm{O}$, r.t., overnight, quant; (iii) $\mathrm{HCl}, 1$,4dioxane, $1 \mathrm{~h}$, r.t.; (iv) $\mathrm{K}_{2} \mathrm{CO}_{3}$, DMF, $15 \mathrm{~min}, 120{ }^{\circ} \mathrm{C}$ microwave heating; (v) $\mathrm{K}_{2} \mathrm{CO}_{3}, \mathrm{Boc}_{2} \mathrm{O}, \mathrm{THF}, 0{ }^{\circ} \mathrm{C}$, overnight; $64 \%$ over three steps; (vi) $\mathrm{OsO}_{4}$ (2.5wt\% in tert-butanol), 1,4-dioxane, 2,6-lutidine, 5 h, r.t. $82 \%$; (vii) $\mathrm{LiAlH}_{4}\left(2.0 \mathrm{M}\right.$ in THF), $50{ }^{\circ} \mathrm{C}, 18 \mathrm{~h}, 88 \%$; (viii) $\mathrm{SOCl}_{2}, \mathrm{CHCl}_{3}$, reflux, 3 h, quant; (ix) $\mathrm{NaOH}, 7, \mathrm{PhCH}_{3}$, reflux, 3 h, $81 \%$.

The optical purity of the target molecule was checked by measurement of the specific rotation and by chiral HPLC. The specific rotations were found to be the same as reported for both enantiomers. ${ }^{30}$ For the chiral HPLC analysis, the method reported by Schaluder et al. was used. ${ }^{40}$ As reported, full separation of the two enantiomers on chiral HPLC was not achieved. Different chiral columns, different eluent mixtures and different base additives were tested, but only partial separation was obtained. However, for the scalemic samples only single peaks were observed. In combination with the specific rotation values, that were the same as reported in the literature, we therefore conclude that our samples were of high enantiopurity.

Minimum inhibitory concentrations (MIC) against different strains of seven bacteria were measured for both enantiomers and the racemate (Table 1 ). Thioridazine racemate and the pure enantiomers were found to be relatively active against the Gram-positive bacteria Mycobacterium samegmatis, Staphylococcus aureus MRSA, Enterococcus faecalis, and Enterococcus faecium, but not effective against the Gram-negative bacteria Escherichia coli and Pseudomonas aeruginosa. The compounds are also slightly active against nosocomial strains of Acinetobacter baumannii, which are difficult to treat in hospitals due to their resistance to most antibiotics. The activities of the enantiomers do not differ significantly from those of the racemic mixture. 
Table 1 Minimum Inhibitory Concentrations (MIC) of Thioridazine $(\mu \mathrm{g} / \mathrm{mL})$ toward a Selected Set of Important Pathogens

\begin{tabular}{|c|c|c|c|}
\hline \multirow[t]{2}{*}{ Bacteria ${ }^{a}$} & \multicolumn{3}{|c|}{ Compound } \\
\hline & $\mathrm{rac}$ & + & - \\
\hline M. smegmatis $(n=2)$ & 10 & 10 & 10 \\
\hline E. faecalis $(n=4)^{\mathrm{b}}$ & 20 & 20 & 20 \\
\hline MRSA $(n=4)$ & $20-40$ & $20-40$ & $20-40$ \\
\hline E. faecium $(n=4)$ & 20 & 20 & $10-20$ \\
\hline A. baumanii $(n=4)^{c}$ & $80-160$ & $80-160$ & $40-160$ \\
\hline E. coli $(n=3)$ & $>1280$ & $>1280$ & $>1280$ \\
\hline P. aeruginosa $(n=2)$ & $>1280$ & $>1280$ & $>1280$ \\
\hline
\end{tabular}

a The number of tested strains of each species given as $n$.

$\mathrm{b}$ Including one nosocomial VRE.

c Nosocomial strains.

In conclusion, both enantiomers of thioridazine have been prepared in high optical purity and good overall yield. ${ }^{41}$ The route via Lemieux-Johnson oxidation of sulfonamide $\mathbf{1 1}$ followed by global reduction to give compound $\mathbf{5}$ proves to be a good, and cheaper alternative to both enantiomers of thioridazine $\mathbf{1}$.

Antimicrobial effects of the two enantiomers are comparable to the effects of the racemate. Of special interest is Mycobacterium smegmatis, as its genus includes harmful pathogens, including Mycobacterium tuberculosis and Mycobacterium leprae. Similar findings were also reported by Poulsen et al. ${ }^{42}$

If the published results by Jensens et al. ${ }^{29}$ on prolongation of the rabbit papillary muscle can be translated to human heart muscle, $(S)-\mathbf{1}$ is potentially a promising target in the fight against pathogens and cancer cells. However, more investigations on the enantiomers are needed to rule out side effects. Further biological tests will be carried out in the near future.

\section{Funding Information}

The authors would like to acknowledge the European Cooperation in Science and Technology (ECOST-STSM-CM1407-42899) for funding SA's short time scientific mission (STSM).

\section{Acknowledgment}

We would like to acknowledge Karoline Gangstad Primdahl for help with chiral HPLC analyses and Roland Kallenborn for lending us the chiral column.

\section{Supporting Information}

Supporting information for this article is available online at https://doi.org/10.1055/s-0039-1690834.

\section{References and Notes}

(1) Fenton, M.; Rathbone, J.; Reilly, J. Cochrane Database Syst. Rev. 2007, 3, CD001944.

(2) Judah, L.; Murphree, O.; Seager, L. Am. J. Psychiatry 1959, 115, 1118.

(3) Kinross-Wright, J. JAMA, J. Am. Med. Assoc. 1959, 170, 1283.

(4) Fletcher, G. F.; Kazamias, T. M.; Wenger, N. K. Am. Heart J. 1969, $78,135$.

(5) Harrigan, E. P.; Miceli, J. J.; Anziano, R.; Watsky, E.; Reeves, K. R.; Cutler, N. R.; Sramek, J.; Shiovitz, T.; Middle, M. J. Clin. Psychopharmacol. 2004, 24, 62.

(6) Hartigan-Go, K.; Bateman, D. N.; Nyberg, G.; Martensson, E.; Thomas, S. H. L. Clin. Pharmacol. Ther. 1996, 60, 543.

(7) Salih, I. S. M.; Thanacoody, R. H. K.; McKay, G. A.; Thomas, S. H. L. Clin. Pharmacol. Ther. 2007, 82, 548.

(8) Mehtonen, O. P.; Aranko, K.; Malkonen, L.; Vapaatalo, H. Acta Psychiatr. Scand. 1991, 84, 58.

(9) Ray, W. A.; Meredith, S.; Thapa, P. B.; Meador, K. G.; Hall, K.; Murray, K. T. Arch. Gen. Psychiatry 2001, 58, 1161.

(10) Reilly, J. G.; Ayis, S. A.; Ferrier, I. N.; Jones, S. J.; Thomas, S. H. L. Br. J. Psychiatry 2002, 180, 515.

(11) Hennessy, S.; Bilker, W. B.; Knauss, J. S.; Margolis, D. J.; Kimmel, S. E.; Reynolds, R. F.; Glasser, D. B.; Morrison, M. F.; Strom, B. L. Br. Med.J. 2002, 325, 1070.

(12) Ray, W. A.; Chung, C. P.; Murray, K. T.; Hall, K.; Stein, C. M. N. Engl. J. Med. 2009, 360, 225.

(13) Reilly, J. G.; Ayis, S. A.; Ferrier, I. N.; Jones, S. J.; Thomas, S. H. L. Lancet 2000, 355, 1048.

(14) Thanacoody, R. H. K. Recent Pat. Anti-Infect. Drug Discovery 2011, 6, 92.

(15) Abbate, E.; Vescovo, M.; Natiello, M.; Cufre, M.; Garcia, A.; Gonzalez Montaner, P.; Ambroggi, M.; Ritacco, V.; van Soolingen, D. J. Antimicrob. Chemother. 2012, 67, 473.

(16) Dastidar, S. G.; Kristiansen, J. E.; Molnar, J.; Amaral, L. Antibiotics 2013, 2, 58.

(17) Amaral, L.; Viveiros, M. Int. J. Antimicrob. Agents 2012, 39, 376.

(18) Ordway, D.; Viveiros, M.; Leandro, C.; Bettencourt, R.; Almeida, J.; Martins, M.; Kristiansen, J. E.; Molnar, J.; Amaral, L. Antimicrob. Agents Chemother. 2003, 47, 917.

(19) Martins, M.; Bleiss, W.; Marko, A.; Ordway, D.; Viveiros, M.; Leandro, C.; Pacheco, T.; Molnar, J.; Kristiansen, J. E.; Amaral, L. In Vivo 2004, 18, 787.

(20) Stenger, M.; Behr-Rasmussen, C.; Klein, K.; Groennemose, R. B.; Andersen, T. E.; Klitgaard, J. K.; Kolmos, H. J.; Lindholt, J. S. PLoS One 2017, e0173362.

(21) Daniel, W. A.; Wojcikowski, J. Toxicol. Appl. Pharmacol. 1999, $158,115$.

(22) Zhang, C.; Gong, P.; Liu, P.; Zhou, N.; Zhou, Y.; Wang, Y. Oncol. Rep. 2017, 37, 1168.

(23) Sachlos, E.; Risueno, R. M.; Laronde, S.; Shapovalova, Z.; Lee, J.H.; Russell, J.; Malig, M.; McNicol, J. D.; Fiebig-Comyn, A.; Graham, M.; Levadoux-Martin, M.; Lee, J. B.; Giacomelli, A. O.; Hassell, J. A.; Fischer-Russell, D.; Trus, M. R.; Foley, R.; Leber, B.; Xenocostas, A.; Brown, E. D.; Collins, T. J.; Bhatia, M. Cell 2012 , $149,1284$.

(24) Cheng, H. W.; Liang, Y. H.; Kuo, Y. L.; Chuu, C. P.; Lin, C. Y.; Lee, M. H.; Wu, A. T. H.; Yeh, C. T.; Chen, E. I. T.; Whang-Peng, J.; Su, C. L.; Huang, C. Y. F. Cell Death Dis. 2015, 6, e1753.

(25) Yue, H.; Huang, D.; Qin, L.; Zheng, Z.; Hua, L.; Wang, G.; Huang, J.; Huang, H. BioMed Res. Int. 2016, 6709828.

(26) Spengler, G.; Csonka, A.; Molnar, J.; Amaral, L. Anticancer Res. 2016, 36, 5701. 
(27) Svendsen, C. N.; Froimowitz, M.; Hrbek, C.; Campbell, A.; Kula, N.; Baldessarini, R. J.; Cohen, B. M.; Babb, S.; Teicher, M. H.; Bird, E. D. Neuropharmacology 1988, 27, 1117.

(28) Jortani, S. A.; Poklis, A. J. Anal. Toxicol. 1993, 17, 374.

(29) Jensen, A. S.; Pennisi, C. P.; Sevcencu, C.; Christensen, J. B.; Kristiansen, J. E.; Struijk, J. J. Eur. J. Pharmacol. 2015, 747, 7.

(30) Bourquin, J. P.; Schwarb, G.; Gamboni, G.; Fischer, R.; Ruesch, L.; Guldimann, S.; Theus, V.; Schenker, E.; Renz, J. Helv. Chim. Acta 1958, 41, 1072.

(31) Choi, S.; Haggart, D.; Toll, L.; Cuny, G. D. Bioorg. Med. Chem. Lett. 2004, 14, 4379.

(32) Bosque, I.; González-Gómez, J. C.; Foubelo, F.; Yus, M. J. Org. Chem. 2012, 77, 780 .

(33) Patrick, K. S.; Singletary, J. L. Chirality 1991, 3, 208.

(34) Mohammad, T.; Hawes, E. M.; McKay, G.; Midha, K. K. J. Labelled Compd. Radiopharm. 1990, 28, 1087.

(35) Mohammad, T.; Midha, K. K.; Hawes, E. M. J. Labelled Compd. Radiopharm. 1988, 25, 415.

(36) Flock, S.; Antonsen, S.; Gallantree-Smith, H.; Langseter, A. M.; Skatteboel, L.; Stenstroem, Y. Tetrahedron Lett. 2016, 72, 4518.

(37) Sun, X.-W.; Liu, M.; Xu, M.-H.; Lin, G.-Q. Org. Lett. 2008, 10, 1259.

(38) Aggarwal, V. K.; Barbero, N.; McGarrigle, E. M.; Mickle, G.; Navas, R.; Suárez, J. R.; Unthank, M. G.; Yar, M. Tetrahedron Lett. 2009, 50, 3482.

(39) Senter, T. J.; Schulte, M. L.; Konkol, L. C.; Wadzinski, T. E.; Lindsley, C. W. Tetrahedron Lett. 2013, 54, 1645.

(40) Schlauderer, F.; Lammens, K.; Nagel, D.; Vincendeau, M.; Eitelhuber, A. C.; Verhelst, S. H. L.; Kling, D.; Chrusciel, A.; Ruland, J.; Krappmann, D.; Hopfner, K.-P. Angew. Chem. Int. Ed. 2013, 52, 10384.

(41) Poulsen, M. Ø.; Klitgaard, J. K.; Christensen, J. B.; Kallipolitis, B. H.; Kaatz, G. W.; Plenge, P.; Fey, S. J.; Kristiansen, J. E. Am. J. Bioavailab. Bioequiv. 2018, $1,1$.

(42) $\mathbf{N}$-Boc (S)-2-(1-methylpiperidin-2-yl)ethanal [(S)-13]: 2-Allyl piperidine (37 $\mathrm{mg}, 0.16 \mathrm{mmol}$ ) was dissolved in dioxane (9.5 $\mathrm{mL})$ and the mixture stirred vigorously for $10 \mathrm{~min}$. 2,6-Lutidine ( $0.038 \mathrm{~mL}, 2$ equiv), $\mathrm{OsO}_{4}$ in tert-butanol $(2.5 \mathrm{wt} \%, 0.047 \mathrm{~mL}$, $0.020 \mathrm{~mol} \%)$, water $(3.2 \mathrm{~mL})$, and $\mathrm{NaIO}_{4}(0.14 \mathrm{~g}, 0.65 \mathrm{mmol}, 4$ equiv) were added and the mixture was stirred for a further $5 \mathrm{~h}$. The reaction was quenched by adding water $(8 \mathrm{~mL}), \mathrm{CH}_{2} \mathrm{Cl}_{2}(16$ $\mathrm{mL}$ ) was added and the phases were separated. The aqueous fraction was further extracted with $\mathrm{CH}_{2} \mathrm{Cl}_{2}(3 \times 16 \mathrm{~mL})$, and the combined organic phases were washed with brine $(16 \mathrm{~mL})$, dried over $\mathrm{Na}_{2} \mathrm{SO}_{4}$, filtered, concentrated under reduced pressure and purified by flash chromatography $\left(\mathrm{SiO}_{2}\right)$ to yield a colorless oil (36.3 mg, quantitative). $[\alpha]_{D}{ }^{20}-51.7\left(c=1, \mathrm{CH}_{3} \mathrm{Cl}\right)\left\{\right.$ lit. $^{43}$ $\left.[\alpha]_{\mathrm{D}}{ }^{20}-50.6\left(c=0.9, \mathrm{CH}_{3} \mathrm{Cl}\right)\right\} ; R_{f}=0.31\left(7: 3 \mathrm{hex} /\right.$ EtOAc). ${ }^{1} \mathrm{H}$ NMR $\left(400 \mathrm{MHz}, \mathrm{CDCl}_{3}\right): \delta=9.71(\mathrm{dd}, J=3.3,2.2 \mathrm{~Hz}, 1 \mathrm{H}), 4.81(\mathrm{~d}, J=$ $8.9 \mathrm{~Hz}, 1 \mathrm{H}), 3.97$ (d, $J=13.8 \mathrm{~Hz}, 1 \mathrm{H}), 2.81-2.66(\mathrm{~m}, 2 \mathrm{H}), 2.51$ $(\mathrm{m}, 1 \mathrm{H}), 1.58(\mathrm{~m}, 2 \mathrm{H}), 1.42(\mathrm{~s}, 10 \mathrm{H}) .{ }^{13} \mathrm{C}$ NMR $(100 \mathrm{MHz}$, $\left.\mathrm{CDCl}_{3}\right): \delta=200.80,154.67,79.90,45.86,44.64,39.24,28.88$, 28.36, 25.21, 18.91 .

(S)-2-(1-Methylpiperidin-2-yl)ethan-1-ol [(S)-5]: To a solution of $(S)-13(0.95 \mathrm{~g}, 4.2 \mathrm{mmol})$ in tetrahydrofuran $(10 \mathrm{~mL})$ at $0{ }^{\circ} \mathrm{C}$ was added $2.0 \mathrm{M}$ lithium aluminum hydride in tetrahydrofuran $(0.28 \mathrm{~mL}, 0.56 \mathrm{mmol})$. The reaction was heated at $50{ }^{\circ} \mathrm{C}$ for 18 hours then cooled to $0{ }^{\circ} \mathrm{C}$, when water $(2.0 \mathrm{~mL}), 1 \mathrm{M}$ aq. $\mathrm{NaOH}(2.0 \mathrm{~mL})$ and water $(2.0 \mathrm{~mL})$ were added successively. The phases were separated, and the organic phase was filtered through a pad of Celite ${ }^{\circledR}$. The filtrate was concentrated under reduced pressure and distilled in vacuo to yield the product as a colorless oil of sufficient purity $(0.53 \mathrm{~g}, 3.7 \mathrm{mmol}, 88 \%)$. The hydrochloride salt was prepared for NMR comparison with the literature. ${ }^{33}[\alpha]_{\mathrm{D}}{ }^{20}-43.9(c=2.5, \mathrm{EtOH})\left\{\mathrm{lit}^{33}[\alpha]_{\mathrm{D}}{ }^{20}-44.2(c=2.5\right.$, EtOH) ${ }^{1} \mathrm{H}$ NMR (400 MHz, $\left.\mathrm{CDCl}_{3}\right): \delta=4.81(\mathrm{br} \mathrm{s}, 1 \mathrm{H}), 3.78(\mathrm{~m}$, $1 \mathrm{H}), 3.59(\mathrm{~m}, 1 \mathrm{H}), 2.80(\mathrm{~m}, 1 \mathrm{H}), 2.26(\mathrm{~s}, 3 \mathrm{H}), 2.10(\mathrm{~m}, 1 \mathrm{H})$, $2.00(\mathrm{dd}, J=11.8,3.5 \mathrm{~Hz}, 1 \mathrm{H}), 1.81(\mathrm{~m}, 1 \mathrm{H}), 1.71-1.36(\mathrm{~m}, 7 \mathrm{H})$, $1.28-1.15(\mathrm{~m}, 1 \mathrm{H}) ;{ }^{13} \mathrm{C}$ NMR $\left(100 \mathrm{MHz}, \mathrm{CDCl}_{3}\right): \delta=61.99,59.95$, 56.61, 42.99, 33.43, 29.47, 25.08, 24.01.

2-(2-Chloroethyl)-1-methylpiperidine [(S)-6]: Thionyl chloride $(0.49 \mathrm{~g}, 0.30 \mathrm{~mL}, 4.1 \mathrm{mmol})$ was added dropwise to a stirred solution of the alcohol $(0.25 \mathrm{~g}, 1.7 \mathrm{mmol})$ in anhydrous chloroform $(15 \mathrm{~mL})$ cooled in an ice bath. After addition was complete, the solution was heated to reflux on a steam bath for 3 hours. Volatiles were removed under reduced pressure and the residual solid was dissolved in $25 \%$ aq. HC1 $(13 \mathrm{~mL})$, treated with activated charcoal and filtered. The solution was evaporated to dryness on a rotary evaporator and the solid obtained was recrystallized from acetone, giving colorless crystals of the hydrochloride salt of $(S)-\mathbf{6}(0.26 \mathrm{~g}$, quantitative yield $) .[\alpha]_{D}{ }^{20}-44$ $\left(c=1, \mathrm{H}_{2} \mathrm{O}\right)\left\{\right.$ lit. $\left.^{33}[\alpha]_{\mathrm{D}}{ }^{20}-44.9\left(c=2, \mathrm{H}_{2} \mathrm{O}\right)\right\} ; \mathrm{mp} 132-133^{\circ} \mathrm{C}\left[\right.$ lit. $^{33}$ $\left.131-132{ }^{\circ} \mathrm{C}\right] .{ }^{1} \mathrm{H}$ NMR $\left(400 \mathrm{MHz}, \mathrm{CDCl}_{3}\right): \delta=3.67-3.49(\mathrm{~m}, 2 \mathrm{H})$, $2.81(\mathrm{~m}, J=11.7,3.7,1.4 \mathrm{~Hz}, 1 \mathrm{H}), 2.25(\mathrm{~s}, 3 \mathrm{H}), 2.15-2.07(\mathrm{~m}$, $3 \mathrm{H}), 1.86(\mathrm{~m}, 1 \mathrm{H}), 1.74-1.62(\mathrm{~m}, 2 \mathrm{H}), 1.61-1.46(\mathrm{~m}, 2 \mathrm{H}), 1.35-$ $1.19(\mathrm{~m}, 2 \mathrm{H}) ;{ }^{13} \mathrm{C}$ NMR $\left(100 \mathrm{MHz}, \mathrm{CDCl}_{3}\right): \delta=61.44,56.90$, 42.94, 41.71, 35.98, 30.47, 25.61, 24.07 .

Thioridazine [(S)-1]: A stirred mixture of phenothiazine 7 $(0.25 \mathrm{~g}, 1 \mathrm{mmol})$, finely powdered $\mathrm{NaOH}(0.16 \mathrm{~g}, 4 \mathrm{mmol})$ and toluene ( $25 \mathrm{~mL}$, dried over activated $4 \AA$ molecular sieves) was heated to reflux for $5 \mathrm{~h}$ under $\mathrm{N}_{2}$ atmosphere. The hydrochloride of $6(0.125 \mathrm{~g}, 0.51 \mathrm{mmol})$ was added portionwise over a period of $1 \mathrm{~h}$. The mixture was then heated to reflux for $3 \mathrm{~h}$, cooled to $0{ }^{\circ} \mathrm{C}$ and the phases were separated. The organic phase was extracted with $25 \%$ aq. $\mathrm{HC} 1(2 \times 50 \mathrm{~mL})$. The aqueous phase was then basified with $\mathrm{NaOH}$ and extracted with $\mathrm{CH}_{2} \mathrm{Cl}_{2}(3 \times 50$ $\mathrm{mL}$ ). The combined organic extracts were washed with water $(25 \mathrm{~mL})$, dried over $\mathrm{Na}_{2} \mathrm{SO}_{4}$, filtered and evaporated on a rotary evaporator. The resulting residue was purified on silica to give $(S)$-thioridazine ( $0.15 \mathrm{~g}, 80 \%$ yield $)$. All spectroscopic data correspond to the data of the racemate. The specific rotation corresponds to that previously published. ${ }^{9}{ }^{1} \mathrm{H}$ NMR $(400 \mathrm{MHz}$, $\left.\mathrm{CDCl}_{3}\right): \delta=7.24-6.75(\mathrm{~m}, 7 \mathrm{H}), 4.05-3.75(\mathrm{~m}, 2 \mathrm{H}), 2.95-2.70$ $(\mathrm{m}, 1 \mathrm{H}), 2.57-2.37(\mathrm{~m}, 3 \mathrm{H}), 2.23-2.18(\mathrm{~m}, 3 \mathrm{H}), 2.15-1.99(\mathrm{~m}$, $3 \mathrm{H}), 1.93-1.79(\mathrm{~m}, 1 \mathrm{H}), 1.78-1.66(\mathrm{~m}, 2 \mathrm{H}), 1.58(\mathrm{qd}, J=9.2$, 7.4, $4.3 \mathrm{~Hz}, 2 \mathrm{H}), 1.50-1.36(\mathrm{~m}, 1 \mathrm{H}), 1.36-1.24(\mathrm{~m}, 1 \mathrm{H}) .{ }^{13} \mathrm{C}$ NMR $\left(100 \mathrm{MHz}, \mathrm{CDCl}_{3}\right): \delta=145.75,145.00,137.54,127.56$, 127.47, 127.22, 125.32, 122.57, 122.26, 120.80, 115.71, 114.61, 62.15, 56.94, 43.97, 43.17, 30.92, 30.05, 25.74, 24.21, 16.50 . $[\alpha]_{D}{ }^{20}-21(c=1$, EtOH $)\left\{\right.$ lit. $^{30}[\alpha]_{D}{ }^{20}-21 \pm 2(c=1$, EtOH $\left.)\right]$; The racemic reference was purchased from Sigma-Aldrich chemicals.

(43) Shaikh, T. M.; Sudalai, A. Eur. J. Org. Chem. 2010, 3437. 